\title{
Enhancing Hydrogen Productivity of Photosynthetic Bacteria from the Formulated Carbon Components of Lignocellulose
}

Chuan Zhang ( $\nabla$ zhangchuancq@126.com )

North China University of Water Resource and Electric Power

\section{Guihong Wang}

North China University of Water Resources and Electric Power

\section{Shuaishuai Ma}

North China University of Water Resources and Electric Power

Hao Huang

North China University of Water Resources and Electric Power

Yixiao Ma

North China University of Water Resources and Electric Power

Zhaoran Li

North China University of Water Resources and Electric Power

\section{Research Article}

Keywords: Photofermentative hydrogen production, lignocellulose, photosynthetic bacterial growth, nitrogenase activity, response surface methodology (RSM)

Posted Date: July 16th, 2021

DOI: https://doi.org/10.21203/rs.3.rs-708580/v1

License: (c) (i) This work is licensed under a Creative Commons Attribution 4.0 International License. Read Full License 


\title{
Enhancing hydrogen productivity of photosynthetic bacteria from the formulated carbon components of lignocellulose
}

Chuan Zhang ${ }^{\mathrm{a}, \mathrm{b}^{*}}$, Guihong Wang ${ }^{\mathrm{a}}$, Shuaishuai Ma ${ }^{\mathrm{a}}$, Hao Huang ${ }^{\mathrm{a}}$, Yixiao Ma ${ }^{\mathrm{a}}$, Zhaoran $\mathrm{Li}^{\mathrm{a}, \mathrm{b}}$

${ }^{\text {a }}$ School of Electric Power, North China University of Water Resource and Electric Power, No.36 Beihuan Road, Jinshui District, Zhengzhou, 450045, People's Republic of China

${ }^{\mathrm{b}}$ Key Laboratory of Low-grad Energy Utilization Technologies and Systems (Ministry of Education), Chongqing Universtity, No. 174 Shazheng Street, Shapingba District, Chongqing, 400044, People's Republic of China

\begin{abstract}
To develop an efficient photofermentative process capable of higher rate biohydrogen production using carbon components of lignocellulosic hydrolysate, a desired carbon substrate by mixing xylose with glucose was formulated. Effects of crucial process parameters affecting cellular biochemical reaction of hydrogen by photosynthetic bacteria (PSB), i.e variation in initial concentration of total carbon, glucose content in initial carbon substrate, as well as light intensity were experimental investigated using response surface methodology (RSM) with a Box-Benhnken design (BBD). Hydrogen production rate (HPR) in the maximum value of $30.6 \mathrm{~mL} \mathrm{~h}^{-1} \mathrm{~L}^{-1}$ was attained under conditions of $39 \mathrm{mM}$ initial concentration of total carbon, $59 \%$ (mol/mol) glucose content in initial carbon substrate and $12.6 \mathrm{~W} \mathrm{~m}^{-2}$ light intensity at light wavelength of $590 \mathrm{~nm}$. Synergic effects of metabolizing such a well formulated carbon substrate for sustaining the active microbial synthesis to sufficiently accumulate biomass in bioreactor, as well as stimulating
\end{abstract}


enzyme activity of nitrogenase for the higher rate biohydrogen production were attributed to this carbon substrate can enable PSB to maintain the relatively consistent microenvironment in suitable culture $\mathrm{pH}$ condition during the optimized photofermentative process.

Keyword:

Photofermentative hydrogen production, lignocellulose, photosynthetic bacterial growth, nitrogenase activity, response surface methodology (RSM)

\section{Introduction}

Hydrogen has been suggested as a promising alternative to fossil fuels for a source of clean energy due to its nature of high energy content $\left(122 \mathrm{~kJ} \mathrm{~g}^{-1}\right)$, recyclability and eco-friendly ${ }^{[1-2]}$. Methods of producing hydrogen through microbial processes have attracted increased attentions of bioenergy engineers in recent years due to its advantage of less energy consuming as compared to traditional ways such as the thermo-chemical or electro-chemical processes, and potential benefits of utilizing natural resources including biomass, water as well as various organic wastes from agriculture, municipalities or industries ${ }^{[3-4]}$. It was considered as a striking technology to produce renewable bioenergy for a sustainable industrial development. The common bioprocesses used for biohydrogen production are biophotolysis of water, dark- or photo-fermentation of organic compounds. Biophotolysis of water into hydrogen using microalgae under sunlight is considered as the cleanest approach. However, oxygen inhibition on hydrogenase activity during the water-splitting 
reaction reduces its productivity. Dark fermentative conversion of carbonhydrate-rich substances into hydrogen by light-independent process with anaerobic bacteria is found to be a faster process, and can occur spontaneously with no external energy requirement from a thermodynamic point of view due to its changes in negative Gibb's free energy ${ }^{[5]}$. While, organic acids formed by dark fermentative hydrogen production could not be further decomposed to hydrogen any more, which resulted in an incomplete degradation of organic wastes. Photosynthetic bacteria (PSB) could use the captured light energy through the action of bacterial photosynthesis in a type of metabolism called photofermentation to overcome the thermodynamic barrier for further conversion of organic compounds into biohydrogen, thus nearly complete biodegratation could be attained. Moreover, PSB have displayed their versatile cellular metabolic pathways in the ability of utilizing a wide variety of carbon substrates, which making photofermentation an attractive technique for simultaneous biohydrogen generation and organic waste treatment ${ }^{[6-8]}$. However, a slower rate of hydrogen productivity accompanied with microbial synthesize of PSB during photofermentation have been recognized by previous studies as compared to those of anaerobic bacteria in dark fermentative process ${ }^{[9]}$. Therefore, more investigations were necessary to explore the potential capability in term of a high rate phototrophic hydrogen production.

Investigations on microbial metabolisms of PSB during bioprocess of photofermentative hydrogen production have revealed that there were a series of biochemical reactions in which the organic matter underwent biodegradation, and 
biohydrogen generation was a result of the protons reduction by the electrons that mainly catalyzed by nitrogenase enzyme ${ }^{[10]}$. Organic carbon can be decomposed during an anaerobic light-depended tri-carboxylic carbon cycle (TCA cycle) to release electrons. Working in parallel was the their photosynthetic membrane apparatus, which transforms the absorbed light energy into the biochemical energy in form of adenosine triphosphate (ATP). Protons were supplied in part by TCA cycle, and the remaining by the action of ATP-synthase within photosynthetic apparatus as aforementioned. Finally, nitrogenase combined the derived electrons with protons to produce hydrogen ${ }^{[11-12]}$. Such an enzymatic biochemical reaction of hydrogen generation involved in photofermentation can be expressed as:

$2 \mathrm{H}^{+}+2 \mathrm{e}^{-}+4 \mathrm{ATP} \rightarrow \mathrm{H}_{2}+4 \mathrm{ADP}+4 \mathrm{Pi}$

Thus, specific regulations for plenty supply of reducing power $\left(\mathrm{e}^{-}\right)$and ATP to promote nitrogenase in their activity of hydrogen production to achieve an efficient photofermentation were necessary.

Lignocellulosic biomass (LCB) was the most abundantly carbohydrates-rich raw material on earth stored plenty of cellulose and hemicellulose, which containing approximately $70-80 \%$ polysaccharide sugars (mainly pentose and hexose) ${ }^{[13]}$. Glucose and xylose were the two most common monomeric sugars that could be liberated after their hydrolysis to be considered as abundance carbon substrates for biohydrogen production ${ }^{[14]}$. Considering PSB exhibited different characteristics in their microbial growth and biohydrogen production from different carbon substrates, investigations on formulating a desired carbon substrate contianing the main carbon 
components of lignocellulosic hydrolysate, i.e., glucose and xylose to attain an efficient photofermentation for a higher rate biohydrogen production were promising. From the engineering point of view, it can offer the prospect of the reduction of the overall cost for the further scale-up of the photofermenative hydrogen production ${ }^{[15]}$. Accordingly, strategies on encourage PSB for efficient conversion of the formulated carbon substrate into biohydrogen via the optimized photofermentation process were needed.

Conventional methods of changing a single factor while setting all of other factors at fixed values to investigate multifactor bioprocess were not only time-consuming but also failed to obtain true optimal operational conditions because possible interactions between these factors were ignored. Thus, statistical experimental design methods were necessary to design experiments for identifying the synergistic effects of process parameters and determining the optimum conditions of photofermentation. As a statistical technique, response surface methodology (RSM) has been successfully applied in the field of biotechnology for designing experiments, building empirical models and evaluating the simultaneous effects of influencing factors $^{[16-17]}$. Therefore, in this study, three factors three levels of a Box-Behnken design (BBD) using response surface methodology (RSM) was applied to investigate impacts of key operational parameters of photofermentative process affecting nitrogenase-catalyzed biochemical reaction of hydrogen generation, which included initial concentration of total carbon, glucose content in initial carbon substrate and light intensity, along with their interactions for maximizing the process performance 
of hydrogen production rate (HPR).

\section{Material and methods}

2.1 Photosynthetic bacteria and experimental procedure

The seeding PSB cells used in this study were isolated from local municipal sewage sludge, and identified as Rhodopseudomonas palustris with steady and high ability for photoheterotrophic hydrogen production $^{[18]}$. The modified RCVBN medium using glucose $\left(6.3 \mathrm{~g} \mathrm{~L}^{-1}\right)$ and urea $\left(1.26 \mathrm{~g} \mathrm{~L}^{-1}\right)$ as the carbon and nitrogen source was used for maintenance of the $\operatorname{strain}^{[19]}$. For biohydrogen production, the seed was anaerobic cultivated for $48 \mathrm{~h}$ at $\mathrm{pH} 7.0,30 \pm 1{ }^{\circ} \mathrm{C}$ under $50 \mathrm{~W} \mathrm{~m}{ }^{-2}$ illumination intensity by tungsten filament lamps to arrive their mid-exponential growth period. Experiments of photofermentative biohydrogen production were performed in batch reactor using conical flasks (Suxiu Biotech Ltd, China) with 1000 $\mathrm{mL}$ working volume. Pre-grown cells were inoculated into reactor with a initial cell concentration of $30 \mathrm{mg} \mathrm{L}^{-1}$ and sparged with oxygen-free argon to achieve an anaerobic environment ${ }^{[20-21]}$.

The schematic diagram of experimental setup was depicted in Fig. 1, which comprised of a magnetic stirrer platform, light-emittingd diode (LED) lamps, bioreator, a liquid conical flask containg $10 \% \mathrm{NaOH}$ for $\mathrm{CO}_{2}$ absorption , and $\mathrm{H}_{2}$ collector. A basal medium for biohydrogen generation was composed as (unit in $\mathrm{g} \mathrm{L}^{-1}$ ): $\mathrm{CO}\left(\mathrm{NH}_{2}\right)_{2} \quad 0.63, \mathrm{KH}_{2} \mathrm{PO}_{4} 0.544, \mathrm{~K}_{2} \mathrm{HPO}_{4} \bullet 3 \mathrm{H}_{2} \mathrm{O} \quad 1.006, \mathrm{MgSO}_{4} \bullet 7 \mathrm{H}_{2} \mathrm{O} \quad 0.2, \mathrm{FeSO}_{4} \bullet$ $7 \mathrm{H}_{2} \mathrm{O}$ 0.0417, $\left(\mathrm{NH}_{4}\right)_{6} \mathrm{Mo}_{7} \bullet 4 \mathrm{H}_{2} \mathrm{O} \quad 0.001, \mathrm{ZnSO}_{4} \bullet 7 \mathrm{H}_{2} \mathrm{O} \quad 0.001, \mathrm{CaCl}_{2} \quad 0.01, \mathrm{NaCl} 0.2$, yeast extract 1.0 and trace element solution $1 \mathrm{~mL}$. Synthetic xylose and glucose were 
used as carbon sources to simulate hydrolysis products of $\mathrm{C}_{5}$ and $\mathrm{C}_{6}$ sugars from LCB. The trace element solution contained (in $\mathrm{g} \mathrm{L}^{-1}$ ) riboflavin 1.0, hydrochloride 1.0, nicotinic acid 1.0 and biotin 0.1 . The initial $\mathrm{pH}$ of medium was adjusted 7.0 by $0.1 \mathrm{M}$ $\mathrm{NaOH}$ and HCL. A complete-mixing condition inside the reator was achieved by a magnetic bead and platform at an agitation rate of $100 \mathrm{rpm}$ within the media. Room temperature of $30 \pm 1{ }^{\circ} \mathrm{C}$ was maintained by air condition. Illumination was provided by several $15 \mathrm{~W}$ LED lamps emitting light under wavelength of $590 \mathrm{~nm}$, which was proved to be the suitable wavelength according to our previous studies ${ }^{[18,22]}$. The incident intensities of light are considered as those on the outer surface of bioreactor, which was adjusted by changing the distance between bioreactor and LED lamps.

\subsection{Analytical methods}

The volume of biogas generated was measured by water-replace method after absorption of carbon dioxide by a $10 \% \mathrm{NaOH}$ solution. The hydrogen content in the biogas was measured by a gas chromatograph (model GC7900, Tianmei Co, China) equipped with a thermal conductivity detector (TCD) and a $2.0 \mathrm{~m}$ stainless steel column pack with $5 \AA$ molecular sieve. Argon gas at a flow rate of $25 \mathrm{~mL} \mathrm{~min}^{-1}$ was used as the carrier. The temperature of the injector and colume were $110{ }^{\circ} \mathrm{C}$ and $60{ }^{\circ} \mathrm{C}$, respectively and current was $70 \mathrm{~mA}$. Total $\mathrm{H}_{2}$ gas produced was calculated by the volume and $\mathrm{H}_{2}$ percentage of biogas generated. The intensity and wavelength of light were measured with a PAR quantum sensor (SA-190, USA), and a spectrometer (FZ-A, China), respectively. The liquid samples were collected from the sealed glass vessel at designated time intervals to determine the concentration of cell, residual 
glucose and xylose, as well as $\mathrm{pH}$ value. Density of bacterial cells was estimated by measuring the turbidity of culture broth at $600 \mathrm{~nm}$ using a UV-VIS spectrophotometer (Blue Star B, China). Biomass in the culture solution with certain OD600 value was collected by a centrifuge at rotor speed of $10000 \mathrm{rpm}$ for a period of $15 \mathrm{~min}$, then the supernatant separated after the centrifugation was discarded and the cell pellets were dried in a hot air oven at $80{ }^{\circ} \mathrm{C}$ until constant dry weight was obtained. The value of OD600 was converted to dry cell weight (DCW) concentration via proper calibration (1.0 OD600 approximately equals $0.66 \mathrm{~g} \mathrm{DCW} \mathrm{L}^{-1}$ ). A spectroscopic method of dual-wavelength using phloroglucinol-glacial acetic acid colorimetry at 553 and 425 $\mathrm{nm}$ was used for determing the concentrations of glucose and xylose within the sample supernatant, respectively ${ }^{[23]}$.

\subsection{Data analysis}

Performance and microbial behaviours of PSB on cell growth and biohydrogen production during photofermentation process were evaluated by the logistic model and modified Gompertz equation as described in equation (2) and (3), respectively ${ }^{[21,}$ 22, 24]:

$$
\begin{aligned}
& x=\frac{x_{\max }}{1+e^{-k_{c} t}\left(\frac{x_{\max }}{x_{0}}-1\right)} \\
& H(t)=P \exp \left\{-\exp \left[\frac{R_{m} e}{P}(\lambda-t)+1\right]\right\}
\end{aligned}
$$

Thus, hydrogen production rate (HPR) was defined as

$$
H P R=\frac{\mathrm{P}}{\frac{P}{R_{m}}+\lambda} \frac{1}{V}
$$


Where, $x$ is the cell concentration $\left(\mathrm{g} \mathrm{L}^{-1}\right), \mathrm{x}_{0}$ is the initial cell concentration $\left(\mathrm{g} \mathrm{L}^{-1}\right)$, $\mathrm{x}_{\max }$ is the maximum cell concentratin $\left(\mathrm{g} \mathrm{L}^{-1}\right), \mathrm{k}_{\mathrm{c}}$ is the apparent specific growth rate $\left(\mathrm{h}^{-1}\right), \mathrm{t}$ is the photofermentation time $(\mathrm{h})$, e denoted constant $(2.818282), \mathrm{H}(\mathrm{t})$ denoted cumulative $\mathrm{H}_{2}$ productin $\left(\mathrm{mL} \mathrm{L}_{\text {medium }}{ }^{-1}\right), \mathrm{P}$ is $\mathrm{H}_{2}$ production potential (mL $\mathrm{L}_{\text {medium }}{ }^{-1}$ ), $\mathrm{R}_{\mathrm{m}}$ is the maximum $\mathrm{H}_{2}$ production rate $\left(\mathrm{mL} \mathrm{L}_{\text {medium }}{ }^{-1} \mathrm{~h}^{-1}\right), \lambda$ is the duration of lag phase (h), and V is the working volume of the culture (L).

\subsection{Experimental design and regression analysis}

A statistical $3^{\mathrm{k}}$ Box-Behnken design (BBD) using RSM was applied to optimize photofermentation process for higher rate biohydrogen production, and investigate interactive impacts of three critical process variables, i.e., initial concentration of total carbon $\left(\mathrm{x}_{1}, \mathrm{mM}\right)$, glucose content in initial carbon substrate $\left(\mathrm{x}_{2}, \% \mathrm{~mol} / \mathrm{mol}\right)$ and light intensity $\left(\mathrm{x}_{3}, \mathrm{~W} / \mathrm{m}^{2}\right)$ due to they can significantly influence carbon source and energy source of photofermentation, thus affect HPR. Experiments were employed by varying initial concentration of total carbon $\left(\mathrm{x}_{1}\right)$ from 20 to $50 \mathrm{mM}$, glucose content in initial carbon substrate $\left(\mathrm{x}_{2}\right)$ from 0 to $100 \% \mathrm{~mol} / \mathrm{mol}$, and light intensity $\left(\mathrm{x}_{3}\right)$ from 5.8 to $17.4 \mathrm{~W} / \mathrm{m}^{2}$, their designed range were determined based on our preliminary batch experiments (shown in Table 1).

The actual values of independent factors $\left(\mathrm{x}_{\mathrm{i}}\right)$ were coded as $\mathrm{X}_{\mathrm{i}}$ (i.e. $\left.-1,0,1\right)$ by applying the following equation:

$\mathrm{Xi}=\left(\mathrm{x}_{\mathrm{i}}-\mathrm{X}_{0}\right) / \Delta \mathrm{x}$

Where $\mathrm{x}_{\mathrm{i}}$ is the actual value of independent factor, $\mathrm{x}_{0}$ is the actual value at the center, $\Delta \mathrm{x}$ is the step change value.

HPR was selected as the response variable. The predicted response was calculated 
according to a second-order polynomial equation ${ }^{[18,25]}$ :

$H P R=\beta_{0}+\sum_{j=1}^{k} \beta_{j} x_{j}+\sum_{j=1}^{k} \beta_{j j} x_{j}^{2}+\sum_{i=1}^{k-1} \sum_{j=i+1}^{k} \beta_{i j} x_{i} x_{j}+\varepsilon$

Where HPR is the predicted response variable, $\beta_{0}$ is the constant coefficient, $i$ and $j$ are the index number of patterns, $\mathrm{k}$ is the number of factor, and $\beta_{\mathrm{j}}, \beta_{\mathrm{jj}}$ and $\beta_{\mathrm{ij}}$ are the estimated coefficients from regression of linear, quadratic and interaction effects, respectively. The obtained regression equations were then analyzed using the analysis of variance methodology (ANOVA) to measure the significance and fit of experimental data to the model. Thereafter, the three-dimensional (3D) response surface graphs and two-dimensional (2D) contour plots can be obtained.

\section{Result and discussion}

\subsection{Photo- $\mathrm{H}_{2}$ production performance}

The experimental design consisted of 15 runs including three replicates at center point was conducted. Each run of the experimental design was performed in triplicates with exception of the three central points, then various HPRs (as tabulated in Table 2) were described as the average value from triplicate experiments with standard deviations. In order to obtain the optimal operational conditions leading to the maximum HPR and reveal the interaction effects among three variables, RSM was employed to get the empirical relationship between the response variable of HPR and the influencing process parameters, and two regression quadratic models for the values of variables in the actual and coded experimental units were obtained as:

$$
\mathrm{HPR}_{\text {actual }}=-6.96+0.981 \mathrm{x}_{1}+0.22 \mathrm{x}_{2}+1.88 \mathrm{x}_{3}-0.00113 \mathrm{x}_{1} \mathrm{x}_{2}+0.0138 \mathrm{x}_{1} \mathrm{x}_{3}+0.0019 \mathrm{x}_{2} \mathrm{x}_{3}
$$

$$
-0.0143 \mathrm{x}_{1}^{2}-0.00172 \mathrm{x}_{2}^{2}-0.1 \mathrm{x}_{3}^{2}
$$


$\mathrm{HPR}_{\text {coded }}=29.77+1.30 \mathrm{X}_{1}+1.55 \mathrm{X}_{2}+0.83 \mathrm{X}_{3}-0.85 \mathrm{X}_{1} \mathrm{X}_{2}+1.20 \mathrm{X}_{1} \mathrm{X}_{3}+0.55 \mathrm{X}_{2} \mathrm{X}_{3}$

$$
-3.21 \mathrm{X}_{1}^{2}-4.31 \mathrm{X}_{2}^{2}-3.36 \mathrm{X}_{3}^{2}
$$

Statistical analysis of variance (ANOVA) was used to estimated significance of the fitted BBD model (7) in terms of linear, quadratic and interactions (demonstrated in Table 3). the F-value of 53.7 for this model showed it was significant, proven by the low p-value of 0.0002 which was less than 0.05 , indicating a high statistical significance of the model terms. The linear $\left(\mathrm{x}_{1}, \mathrm{x}_{2}\right.$ and $\left.\mathrm{x}_{3}\right)$, quadratic $\left(\mathrm{x}_{1}{ }^{2}, \mathrm{x}_{2}{ }^{2}\right.$ and $\left.\mathrm{x}_{3}{ }^{2}\right)$ and the interactive effects of $\mathrm{x}_{1} \mathrm{x}_{2}$ and $\mathrm{x}_{1} \mathrm{x}_{3}$ were significant $(\mathrm{p}<0.05)$. While, $\mathrm{x}_{2} \mathrm{x}_{3}$ was considered not significant by the p-value greater than 0.05 , implying the interactive effect between glucose content in initial substrate $\left(\mathrm{x}_{2}\right)$ and light intensity $\left(\mathrm{x}_{3}\right)$ has little impact on HPR, whereas it still be retained in Eq. (7) due to it is a hierarchical model. The lack-of-fit F-value in 1.71, which corresponded to a p-value of 0.1019, indicated this model fits the data well and can be used to describe biohydrogen production performance of PSB during photofermentation of the formulated carbon source. The measure of the goodness of fit $\left(\mathrm{R}^{2}=0.9898\right)$ was close to 1.0 , which showed a good agreement between observed values of experiment and predicted values of the model. Adequate precision measures the signal to noise ratio. A ratio greater than 4.0 was desired, in this model the ratio of 22.697 indicated an adequate signal. The coefficient of variation $(\mathrm{CV})$ in $2.53 \%$ showed that this model can be considered reasonably reproducible because the $\mathrm{CV}$ is less than $10 \%$. Consequently, the model can be employed to navigate the design space.

3.2 Effects of initial concentration of total carbon and light intensity on HPR

3D surface graph and 2D contour plot indicating HPR with respect to initial 
concentration of total carbon $\left(\mathrm{x}_{1}\right)$ and light intensity $\left(\mathrm{x}_{3}\right)$ at constant glucose content in initial carbon substrate $\left(\mathrm{x}_{2}\right)$ of $59 \% \mathrm{~mol} / \mathrm{mol}$ were illustrated in Fig. 2. As shown from the $3 \mathrm{D}$ surface graph, for the studied range of $\mathrm{x}_{1}$ from 20 to $39 \mathrm{mM}$, and $\mathrm{x}_{3}$ from 5.8 to $12.6 \mathrm{~W} \mathrm{~m}^{-2}$, HPR was observed to increase as the two variables increased. While, after reaching a peak value of $30.0 \mathrm{mLh}^{-1} \mathrm{~L}^{-1}$, HPR decreases even if the two variables continue to increase. The 3D surface graph also revealed that HPR was more sensitive to the change of light intensity from 5.8 to $12.6 \mathrm{~W} \mathrm{~m}^{-2}$ than that of initial substrate concentration from 20 to $39 \mathrm{mM}$. Moreover, the 2D contour plot was elliptical with elongated diagonals indicating there is a significant interactive effect between initial concentration of total carbon and light intensity. Experimental results confirmed that there was a close relationship among the cellular metabolisms of organic carbon degradation for electron release, microbial photosynthesis for the conversion of light energy into ATP, and the nitrogenase-catalyzed reaction of biohydrogen generation. From the perspective of process operation, a higher HPR is likely the result of process optimization for the sufficient providing of both electrons and ATPs by an appropriate combination of initial concentration of total carbon and light intensity to promote the activity of nitrogenase in catalyzing the reaction of biohydrogen generation.

3.3 Effects of initial concentration of total carbon and glucose content in initial carbon substrate on HPR

Effects of initial concentration of total carbon $\left(\mathrm{x}_{1}\right)$ and glucose content in initial carbon substrate $\left(\mathrm{x}_{2}\right)$ on HPR were depicted in Fig. 3. Significant individual effects of the two variables and their interactions that influence biohydrogen production were 
demonstrated, and the highest value of HPR was achieved within the range of process operational process paramters investigated. It is also revealed that HPR was more sensitive to change in glucose content in initial carbon substrate, as it exhibited a steeper slope on the axis of $\mathrm{x}_{2}$ compared to the axis of $\mathrm{x}_{1}$. So, type of carbon source is considered to be a significant factor affecting intracellular metabolisms of both cell synthesis and biohydrogen production. The different components of the mixed carbon likely partition to synthesis of new cells for microbial growth and production of hydrogen to different extents due to their different cellular metabolic pathways to be utilized by PSB during the photofermentative process. A mixed carbon source that was well formulated by RSM with a particular combination of initial concentration of total carbon $\left(\mathrm{x}_{1}\right)$ and glucose content in initial carbon substrate $\left(\mathrm{x}_{2}\right)$ can likely balance the eletrons allocation between cell growth and biohydrogen production during the optimized operational conditions. Accordingly, both efficient growth of PSB cells to increase level of nitrogenase within bioreactor, i.e. to produce sufficient bomass, and stimulation of the enzyme activity for nitrogenase to catalyze biohydrogen production can be attained, which resulted in the highest HPR.

\subsection{Optimization analysis and verification test}

The optimum operational parameters of photofermentation for maximizing HPR, determined by setting the partial derivatives of $\mathrm{Eq}(7)$ to zero with respect to the corresponding variables. Initial concentration of total carbon $\left(\mathrm{x}_{1}\right)$ at $39 \mathrm{mM}$, glucose content in initial carbon substrate $\left(\mathrm{x}_{2}\right)$ at $59 \% \mathrm{~mol} / \mathrm{mol}$ and light intensity $\left(\mathrm{x}_{3}\right)$ of 12.6 $\mathrm{Wm}^{-2}$ were thus obtained. To test the validity of the predicted maximum HPR, verify 
experiments were conducted under the obtained process parameters, resulting in HPR of $30.6 \pm 0.2 \mathrm{~mL} \mathrm{~h}^{-1} \mathrm{~L}^{-1}(\mathrm{~N}=3)$, which is close to the predicted value of $30.0 \mathrm{~mL} \mathrm{~h}^{-1}$ $\mathrm{L}^{-1}$ from the regression model, suggesting the experimental and predicted HPR were in good agreement. The correlation between the predicted and actual process conditions verified validation of the model as well as the exsitence of an optimal point.

3.5 Investigation on effect of different carbon substrates by single factor parallel experiments

To reveal the synergistic effects of various organic carbons on performances of PSB during photofermentation, single factor parallel experiments using pure xylose, pure glucose, as well as this formulated carbon substrate on the basis of equal initial concentration of $39 \mathrm{mM}$ were conducted under aforementioned optimum conditions. Profiles of cell growth, cumulative $\mathrm{H}_{2}$ volume and the $\mathrm{pH}$ value, as well as carbon substrate consumption were investigated and coupled with kinetic analysis as shown in Figs 4, 5 and 6, respectively.

The microbial growth curves in Figs 4(a) - 4(c) exhibited three typical stages of their lag, exponential and stationary phases using various carbon substrates. All of cell growth curves were fitted well with the logistic model, thus the values of growth kinetic parameters can be obtained. It demonstrated that cell growth commenced from the pure xylose, glucose and the formulated carbon substrate with a lag time of about 9.0, 6.2, and $7.0 \mathrm{~h}$ after inoculation, then progressing well at different apparent growth rate $\left(\mathrm{k}_{\mathrm{c}}\right)$ of $0.136 \mathrm{~h}^{-1}, 0.19 \mathrm{~h}^{-1}$ and $0.176 \mathrm{~h}^{-1}$ into their stationary phases, and attained the final concentrations of cell in $0.79,0.88$ and $0.976 \mathrm{~g} \mathrm{~L}^{-1}$, respectively. The 
production of $\mathrm{H}_{2}$ as illustrated in Figs 5(a) - 5(c) started after 12.1, 8.7, and 10.2 h lag phase of photofermentation and obtained the cumulative $\mathrm{H}_{2}$ in volumes of 941,1078 , and $1447 \mathrm{~mL}$, then ceased at 66, 60 and $72 \mathrm{~h}$, respectively. Experimental results indicated that both glucose and xylose can be utilized by PSB cells for cell growth and biohydrogen production, but pure glucose or the formulated carbon substrate can led to a shorter lag phase than pure xylose. This indicated that glucose was more readily metabolized by PSB. While, the longer duration time in both cell growth and biohydrogen production can be obtained from the formulated carbon substrate rather than pure glucose, thus resulted in a higher productivity of biohydrogen. The reasons were attributed to the formulated carbon substrate can enable PSB cells to flexibly select and activate their metabolic pathways such as the oxidative TCA cycle or pentose phosphate pathway (PPP) for the efficient providing of reducing equivalents, and affect rate of consuming them via biomass synthesis or biohydrogen production, thereby enabling PSB cells to maintian their redox homeostasis. So, a near neutral net balance of formation of intermediate products especially volatile fatty acids and their consumption during the RSM-optimized photofermentation process can be achieved, and resulted in a relative neutral $\mathrm{pH}$ condition in the biosystem when compared with photofermentation from pure glucose, as exhibited in Figs 5(b) and 5(c). Biohydrogen production was usually accompanied by formation of intermediates such as VFAs and solvents, which reflected metabolic pathways of the microorganisms used for organic carbon metabolism under the certain process conditions. Performances of PSB on substrate consumption using different organic carbons were fitted well with modified 
Gompertz models (as indicated in Fig 6). The formulated carbon substrate demonstrated the highest cumulative carbon consumption in $36.6 \mathrm{mM}$ as compared to pure glucose or pure xylose, and achieved the highest carbon degradation efficiency in 93.8\%. The relatively consistent microenvironment condition with culture $\mathrm{pH}$ near neutral by using the formulated carbon substrate can positive influence PSB cells in controlling the microenvironment at an optimal range to maintain the higher activity of various intracellular enzymes affecting carbon metabolism, and resulted in efficient degradation and utilization of carbon sources for improving electron availability for microbial synthesis as well as biohydrogen production. Consequently, a comparative high apparent specific growth rate $\left(\mathrm{k}_{\mathrm{c}}\right)$ in $0.176 \mathrm{~h}^{-1}$ was achieved for PSB to obtain peak cell density of $0.976 \mathrm{~g} \mathrm{~L}^{-1}$ within the biosystem, which were fairly high values as compared with previous studies (as shown in Table 4). Meantime, the highest values of cell biomass yield in $0.163 \mathrm{~g} \mathrm{CWD} / \mathrm{g}$ carbon, $\mathrm{H}_{2}$ yield in $1.77 \mathrm{molH}_{2} / \mathrm{mol}$ carbon and substrate degradation efficiency (SDE) in $93.8 \%$ were thus achieved (as shown in Figs 4(c), 5(c) and 6(c)), demonstrating an efficient bioconversion of this formulated carbon substrate during this photofermentation process.

\subsection{Comparison with previous studies}

An examination of results from the relevant literature reports on the enhancing biohydrogen production of photofermentation showed that PSB in this study performed well (shown in table 5). At $39 \mathrm{mM}$ initial substrate concentration, $59 \% \mathrm{~mol} / \mathrm{mol}$ glucose content in initial substrate, and light intensity of $12.6 \mathrm{~W} \mathrm{~m}^{-2}$, a higher rate of $\mathrm{H}_{2}$ production at $30.6 \pm 0.2 \mathrm{~mL} \mathrm{~h}^{-1} \mathrm{~L}^{-1}$ was achieved. It was higher than 
most of other previous studies, including those that used various DOE (design of experiments) methods to achieve the maximal $\mathrm{H}_{2}$ production. The improved performance of $\mathrm{H}_{2}$ production obtained in this study demonstrated that PSB could perform an efficient photofermentation process to direct the majority of electrons from this well formulated carbon substrate into metabolism of biomass accumulation and $\mathrm{H}_{2}$ production under the optimized operational conditions. Meanwhile, a much smaller diversion of substrate was converted into by-products such as organic acids or solvents which hard to be degraded by TCA cycle and disturbed microenvironment around PSB cells. So, the percent of electrons found in biohydrogen is higher, which resulted in the higher HPR.

\section{Conclusions}

Strategies to develope a high-rate photofermentative hydrogen production process from main carbon components of lignocellulosic hydrolysate were explored by optimizing crucial operational process parameters, i.e. initial substrate concentration, glucose content in initial substrate as well as light intensity using RSM with BBD. The determined bioprocess parameters for achieving the maximal HPR of $30.6 \mathrm{~mL} \mathrm{~h}^{-1} \mathrm{~L}^{-1}$ were identified as $39 \mathrm{mM}$ initial substrate concentration, $59 \% \mathrm{~mol} / \mathrm{mol}$ glucose in initial substrate and light intensity of $12.6 \mathrm{~W} \mathrm{~m}^{-2}$ at light wavelength of 590 $\mathrm{nm}$.

Experimental investigations demonstrated that the strain of PSB showed their metabolic versatility and capable of consuming both glucose and xylose for microbial growth, as well as biohydrogen production. The RSM with BBD can be applied as an 
efficient and feasible tool to formulated a carbon source in suitable content and initial total carbon concentation for their sufficient degradation during the optimized photofermentation process under a relative neutral $\mathrm{pH}$ culture condition, thus maintaining higher activity of their various intracellular enzymes to facilitate biomass accumulation to attain an appropriate cell concentration of PSB within bioreactor (i.e. to obtain a suitable amount of nitrogenase within biosystem), as well as maintain the specific catalytic activity of nitrogenase by saturating their demand of reducing power (electrons) and ATP energy in driving the cellular hydrogen producing reaction, which resulted in the enhanced performance of biohydrogen production.

\section{Ethical Approval}

Not applicable.

\section{Consent to Participate}

Informed consent was obtained from all individual participants included in the study.

\section{Consent to Publish}

All the authors accept that the copyright of the manuscript will be transferred to the journal upon acceptance for publication.

\section{Authors Contributions}

Conceptualization, methodology, data curation, supervision and writing-review and editing: Chuan Zhang. Investigation and writing-original draft: Guihong Wang. Investigation and writing-review and editing: Shuaishuai Ma. Investigation: Hao Huang. Writing-review and editing: Yixiao Ma. Writing-review and editing: Zhaoran Li. All the authors read and approved the final manuscript. 


\section{Corresponding author}

Correspondence to Chuan Zhang. E-mail address: zhangchuancq@126.com, zhangchuan@cqu.edu.cn.

\section{Funding}

This work was support by the Natural Science Foundation of China (Grant No. 51376056) and the Scientific Reseach Project of High Education in Henan Province (Grant No. 21A480006).

\section{Competing Interests}

The authors declare no competing interests.

\section{Availability of data and materials}

The materials and datasets used or analyzed during the present study are available from the corresponding author on reasonable request.

\section{References}

[1] Hallenbeck PC, Hashesh MA, Ghosh D. Strategies for improving biological hydrogen production. Bioresource Technology 2012; 110: 1-9.

[2] Basak N, Jana AK, Das D, Saikia D. Photofermentative molecular biohydrogen production by purple-non-sulfur (PNS) bacteria in various modes: The present progress and future perspective. International Journal of Hydrogen Energy 2014; 39: 6853-6871.

[3] Chandrasekhar K, Kumar S, Lee BD, Kim SH. Waste based hydrogen production for circular bioeconomy: Current status and future directions. Bioresource Technology 2020; 302: 122920.

[4] Tiang MF, Hanipa MAF, Abdul PM, Jahim JMD, Mahmod SS, Takriff MS, Lay $\mathrm{CH}$, Reungsang A, Wu SY. Recent advanced biotechnological strategies to enhance photo-fermentative biohydrogen production by purple non-sulphur bacteria: An overview. International Journal of Hydrogen Energy 2020; 45: 13211-13230. 
[5] Azwar MY, Hussain MA, Abdua-Wahab AK. Development of biohydrogen production by photobiological, fermentation and electrochemical processes: A review. Renewable and Sustainable Energy Reviews 2014; 31: 158-173.

[6] Ghosh S, Dairkee UK, Chowdhury R, Bhattacharya P. Hydrogen from food processing wastes via photofermentation using purple non-sulfur bacteria (PNSB)- A review. Energy Conversion and Management 2017; 141: 299-314.

[7] Wu TY, Hay JXW, Kong LB, Juan JC, Jahim JM. Recent advances in reuse of waste material as substrate to produce biohydrogen by purple non-sulfur (PNS) bacteria. Renewable and Sustainable Energy Reviews 2012; 16: 3117-3122.

[8] Chen CY, Yeh KL, Lo YC, Wang HM, Chang JS. Enigeering strategies for the enhanced photo- $\mathrm{H}_{2}$ production using effluents of dark fermentation processes as substrate. International Journal of Hydrogen Energy 2010; 35: 13356-13364.

[9] Hallenbeck PC, Liu Y. Recent advances in hydrogen production by photosynthetic bacteria. International Journal of Hydrogen Energy 2016; 41: 4446-4454.

[10] Koku H, Eroğlu İ, Gündüz U, Yücel M, Türker L. Aspects of the metabolism of hydrogen production by Rhodobacter sphaerodies. International Journal of Hydrogen Energy 2002; 27: 1315-1329.

[11] Akkerman I, Janssen M, Rocha J, Wijffels RH. Photobiological hydrogen production: photochemical efficiency and bioreactor design. International Journal of Hydrogen Energy 2002; 27: 1195-1208.

[12] Arimi MM, Knodel J, Kiprop A, Namango SS, Zhang YJ, Geißen. Strategies for improvement of biohydrogen production from organic-rich wastewater: A review. Biomass \& Bioenergy 2015; 75: 101-118.

[13] Bhatia SK, Kim SH, Yoon JJ, Yang YH. Current status and strategies for second generation biofuel production. Energy Conversion and Management 2017; 148: 1142-1156.

[14] Kumar G, Bakonyi P, Periyasamy S, Kim SH, Nemestóthy N, Bélafi-Bakó K. Lignocellulose biohydrogen: Practical challenges and resent progress. Renewable and Sustainable Energy Reviews 2015; 44: 728-737.

[15] Ren NQ, Zhao L, Chen C, Guo WQ, Cao GL. A review on bioconversion of lignocellulosic biomass to $\mathrm{H}_{2}$ : Key challenges and new insights. Bioresource Technology 2016; 215: 92-99.

[16] Lazaro CZ, Hitit ZY, Hallenbeck PC. Optimization of the yield of dark microaerobic production of hydrogen from lactate by Rhodopseudomonas palustris. 
Bioresource Technology 2017, 245: 123-131.

[17] Yu HQ, Shi XY. Response surface analysis on the effect of cell concentration and light intensity on hydrogen production by Rhodopseudomonas capsulata. Process Biochemistry 2005; 40: 2475-2481.

[18] Zhang C, Ma SS, Wang GH, Guo YP. Enhancing continuous hydrogen production by photosynthetic bacterial biofilm formation within an alveolar panel photobioreactor. International Journal of Hydrogen Energy 2019, 44: 27248-27258.

[19] Zhang C, Zhu X, Liao Q, Wang YZ, Li J, Ding YD, Wang H. Performance of a groove-type photobioreactor for hydrogen production by immobilized photosynthetic bacteria. International Journal of Hydrogen Energy 2010; 35(21): 5284-5292.

[20] Koku H, Eroğlu İ, Gündüz U, Yücel M, Kürker L. Kinetics of biological hydrogen production by the photosynthetic bacterium Rhodobacter sphaeroides O.U.001. International Journal of Hydrogen Energy 2003, 28: 381-388.

[21] Savinc P, Güendüez U, Eroglu I, Yücel M. Kinetic analysis of photosynthetic growth, hydrogen production and dual substrate utilization by Rhodobacter capsulatus[J]. International Journal of Hydrogen Energy, 2012; 37(21):16430-16436.

[22] Xie GJ, Liu BF, Xing DF, Ding J, Nan J, Ren HY, Guo WQ, Ren NQ. The kinetic characterization of photofermentative bacterium Rhodopseudomonas faecalis RLD-53 and its application for enhancing continuous hydrogen production. International Journal of Hydrogen Energy 2012;37: 13718-13724.

[23] Zhou FL, Wang CW, Wei J. Simultaneous acetic acid separation and monosaccharide concentration by reverse osmosis. Bioresource Technology 2013; 131: 349-356.

[24] Su HB, Cheng J, Zhou JH, Song WL, Cen KF. Combination of dark- and photo-fermentation to enhance hydrogen production and energy conversion. International Journal of Hydrogen Energy 2009; 34(21): 8846-8853.

[25] Hitit ZY, Lazaro CZ, Hallenbeck PC. Hydrogen production by co-cultures of Clostridium butyricum and Rhodopseudomonas palustris: optimization of yield using response surface methodology. International Journal of Hydrogen Energy 2017; 42: 6578-6589.

[26] Eroğlu E, Gündüz U, Yücel, M, Türker L, Eroğlu İ. Photobiological hydrogen production by using olive mill wastewater as a sole substrate source. International Journal of Hydrogen Energy 2004; 29:163-171.

[27] Eroğlu E, Gunduz U, Yucel M, Eroglu İ. Photosynthetic bacterial growth and 
productivity under continuous illumination or diurnal cycles with olive mill wastewater as feedstock. International Journal of Hydrogen Energy 2010; 35:5293-5300.

[28] Androga DD, Uyar B, Koku H, Eroglu İ. Implementation and analysis of temperature control strategies for outdoor photobiological hydrogen production. Bioprocess and Biosystems Engineering 2016; 39:1913-1921.

[29] He D, Bultel Y, Magnin JP, Willison JC. Kinetic analysis of photosynthetic growth and photohydrogen production of two strains of Rhodobacter Capsulatus. Enzyme and Microbial Technology 2006; 38:253-259.

[30] Pekgöz G, Gündüz U, Eroğlu İ, Yücel M. Effect of inactivation of genes involved in ammonium regulation on the biohydrogen production of Rhodobacter capsulatus. International Journal of Hydrogen Energy 2011; 36:13536-13546.

[31] Eroğlu İ, Tabanoğlu A, Gündüz U, Eroğlu E, Yücel M. Hydrogen production by Rhodobacter sphaeroides O.U.001 in a flat plate solar bioreactor. International Journal of Hydrogen Energy 2008; 33: 531-541.

[32] Gilbert JJ, Ray S, Das D. Hydrogen production using Rhodobacter sphaeroides (O.U. 001) in a flat panel rocking photobioreactor. International Journal of Hydrogen Energy 2011; 36:3434-3441.

[33] Basak N, Jana AK, Das D. CFD modeling of hydrodynamics and optimization of photofermentative hydrogen production by Rhodopseudomonas palustris DSM 123 in annular photobioreactor. International Journal of Hydrogen Energy 2016; 41:7301-7317

[34] Cardeña R, Moreno G, Valdez-Vazquez I, Buitrón G. Optimization of volatile fatty acids concentration for photofermentative hydrogen production by a consortium. International Journal of Hydrogen Energy 2015; 40:17212-17223.

[35] Androga DD, Sevinc P, Koku H, Yücel Y, Gündüz U, Eroğlu İ. Optimization of temperature and light intensity for improved photofermentative hydrogen production using Rhodobacter capsulatus DSM 1710. International Journal of Hydrogen Energy 2014; 39: 2472-2480.

[36] Assawamongkholsiri T, Alissar R. Photo-fermentational hydrogen production of Rhodobacter sp. KKU-PS1 isolated from an UASB reactor. Electronic Journal of Biotechnology 2015; 18:221-230.

[37] Jiang D, Ge X, Lin L, Zhang T, Liu H, Hu J, Zhang QG. Continuous photo-fermentative hydrogen production in a tubular photobioreactor using corn stalk pith hydrolysate with a consortium. International Journal of Hydrogen Energy 2020; 
[38] Al-Mohammedawi HH, Znad H, Eroglu E. Synergistic effects and optimization of photo-fermentative hydrogen production of Rhodobacter sphaeroides DSM 158. International Journal of Hydrogen Energy 2018; 43:15823-15834.

[39] Zhu X, Xie X, Liao Q, Wang Y Z, Lee DJ. Enhanced hydrogen production by Rhodopseudomonas palustris CQK 01 with ultra-sonication pretreatment in batch culture. Bioresource Technology 2011; 102:8696-8699.

[40] Akman MC, Tuba H, Erguder, Gündüz U.Eroğlu I. Investigation of the effects of initial substrate and biomass concentrations and light intensity on photofermentative hydrogen gas production by Response Surface Methodology. International Journal of Hydrogen Energy 2015; 40: 5042-5049.

[41] Chen CY, Lu WB, Wu JF, Chang JS. Enhancing phototrophic hydrogen production of Rhodopseudomonas palustris via statistical experimental design. International Journal of Hydrogen Energy 2007; 32:940-949. 
Figures

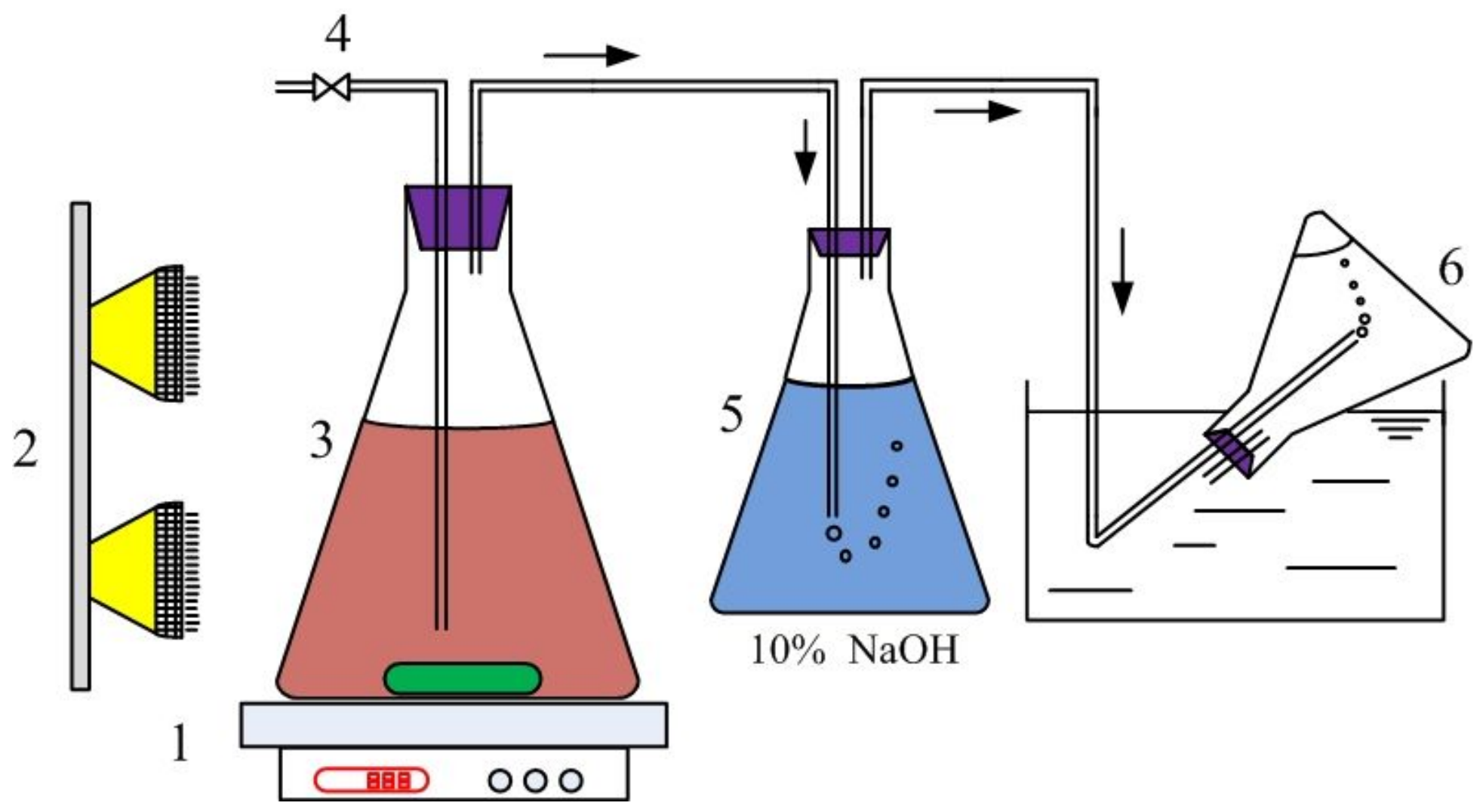

Figure 1

Experimental setup for photofermentative $\mathrm{H} 2$ production using mixed carbon 


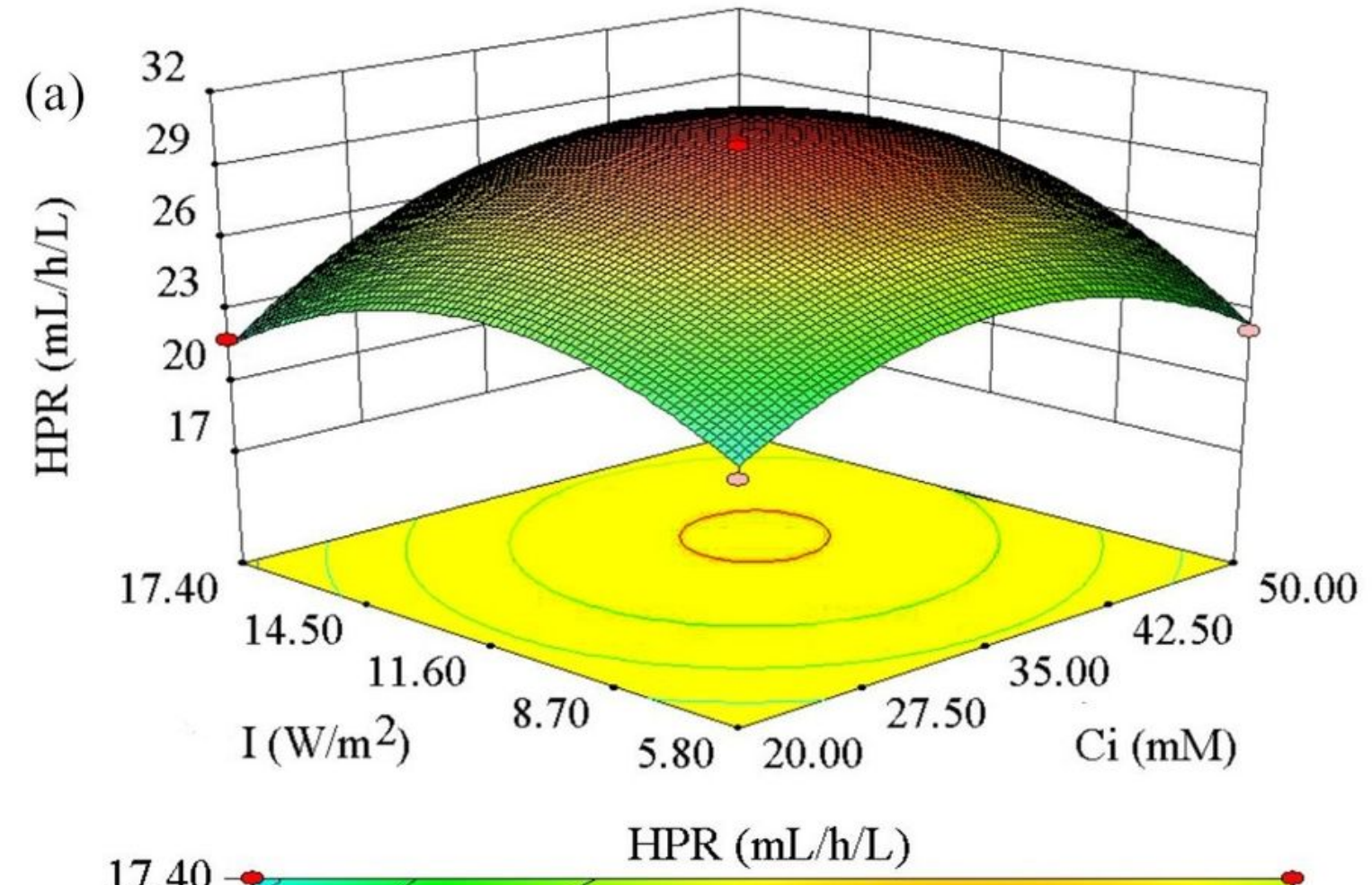

(b)

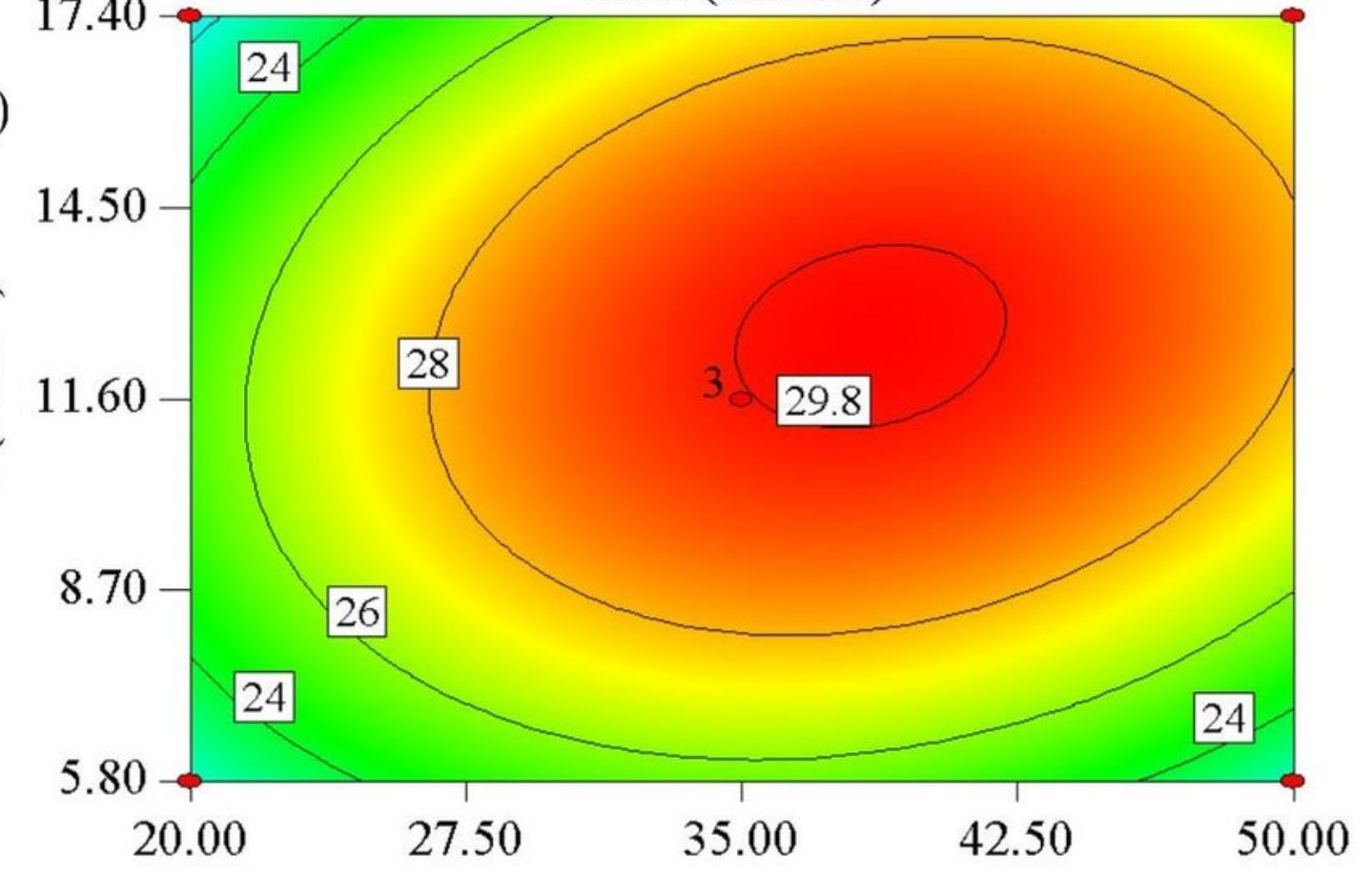

$\mathrm{Ci}(\mathrm{mM})$

\section{Figure 2}

Effects of initial concentration of total carbon and light intensity on HPR at constant glucose content in initial carbon substrate of $59 \% \mathrm{~mol} / \mathrm{mol}$ (a) 3D surface graph, and (b) 2D contour plot 


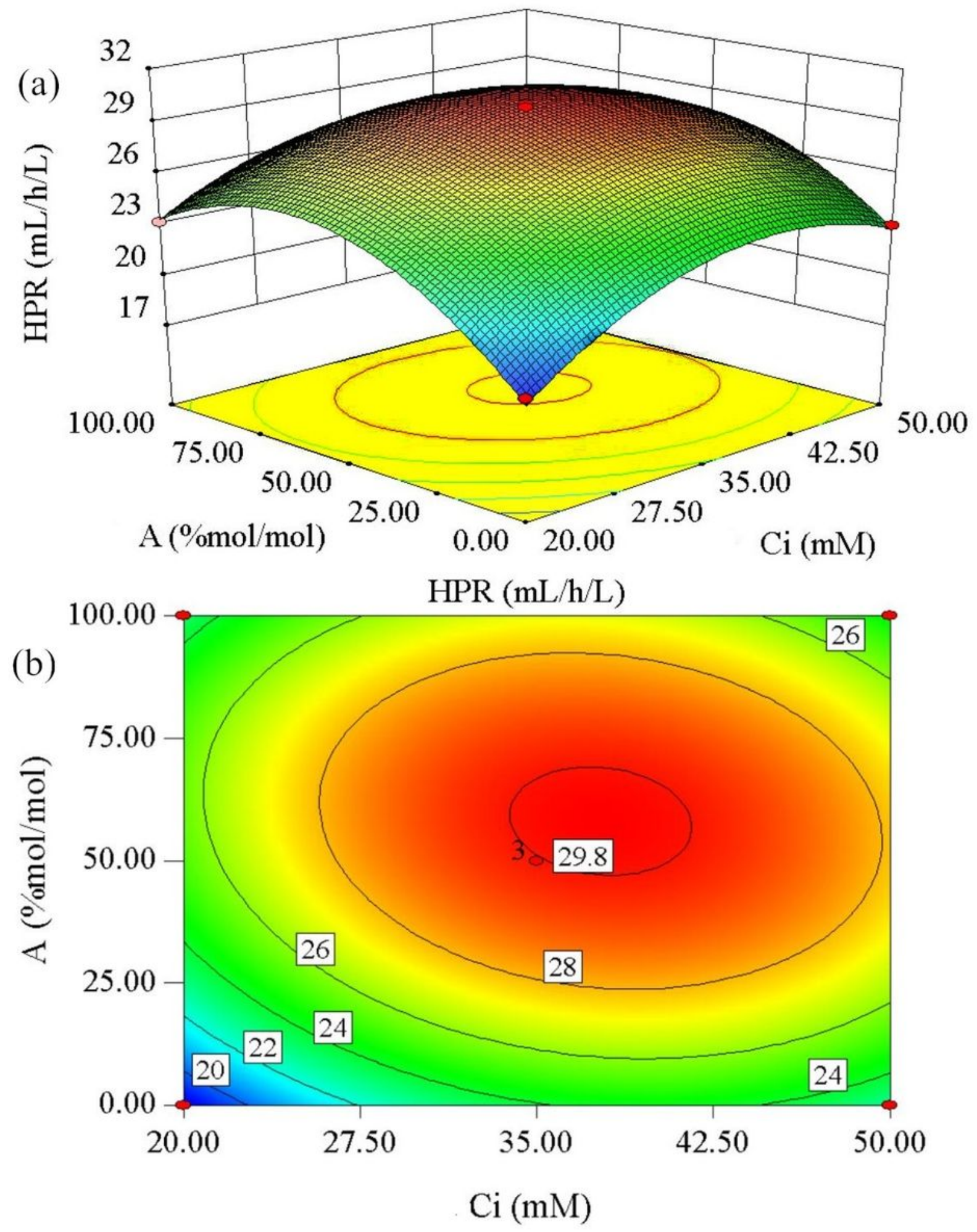

Figure 3

Effects of initial concentration of total carbon and glucose content in initial carbon substrate on HPR at constant light intensity of $12.6 \mathrm{~W} / \mathrm{m} 2$ (a) 3D surface graph, and (b) 2D contour plot 

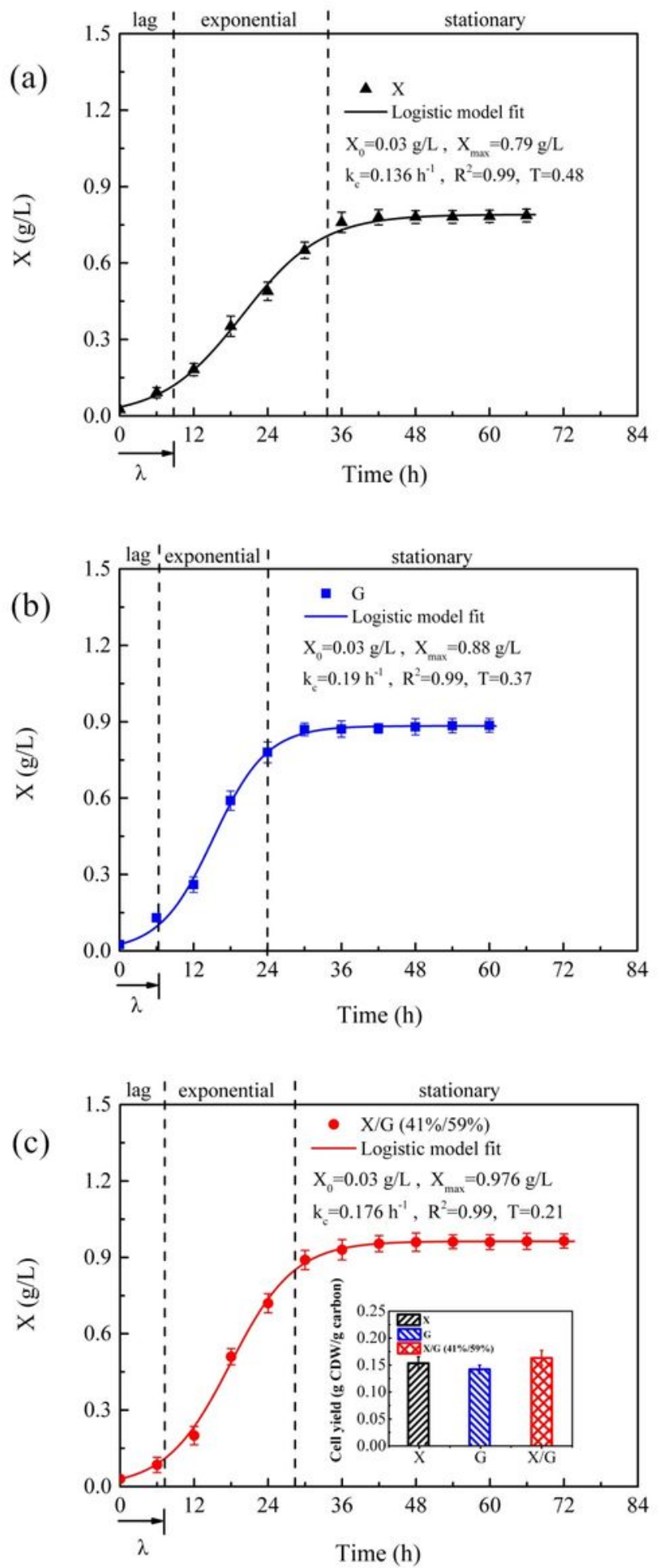

\section{Figure 4}

Profiles of cell growth at optimum conditions from (a) pure xylose, (b) pure glucose and (c) the formulated carbon substrate 
(a)
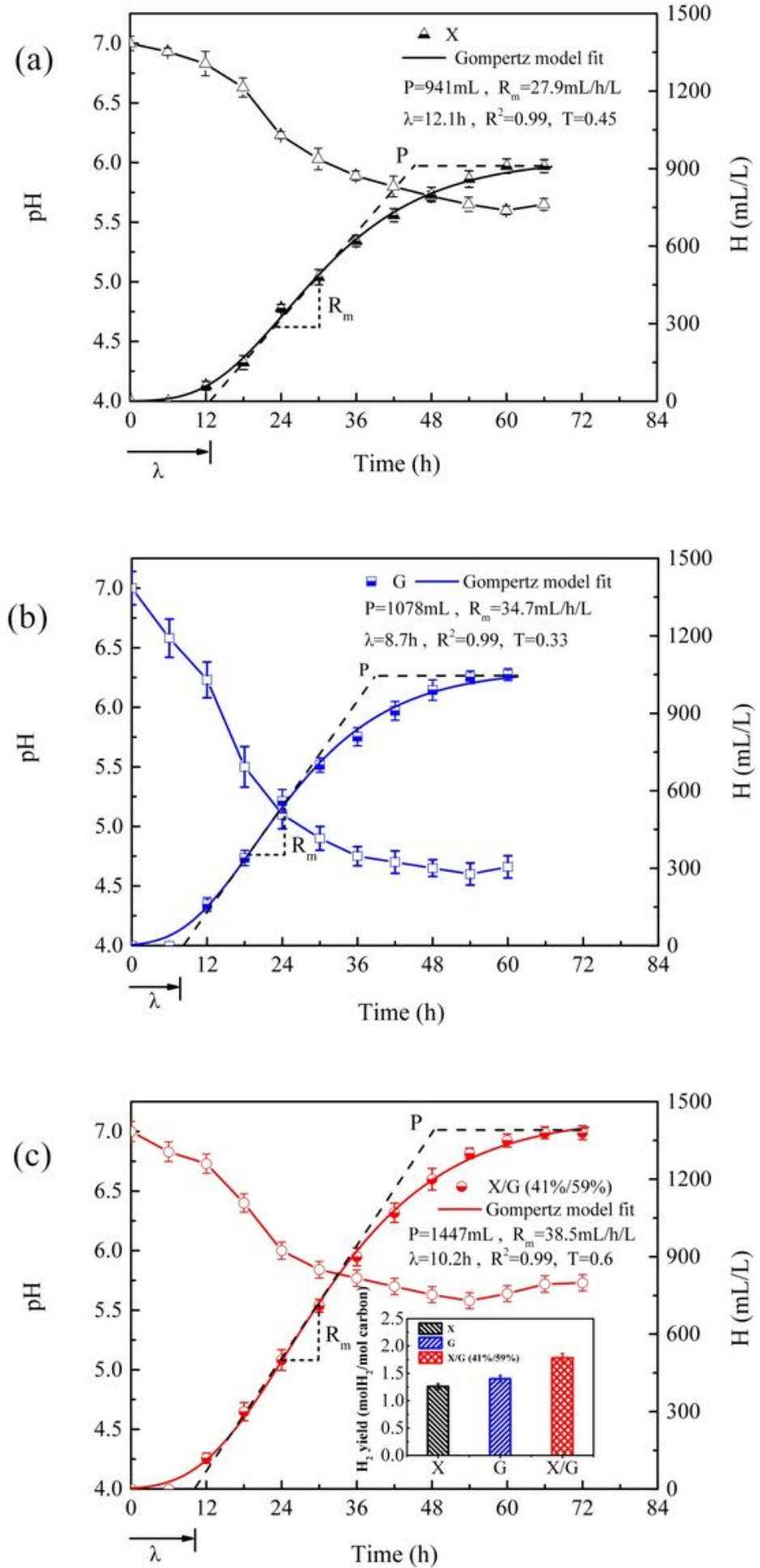

Figure 5

Cumulative $\mathrm{H} 2$ production and pH profiles at optimum conditions from (a) pure xylose, (b) pure glucose and (c) the formulated carbon substrate 

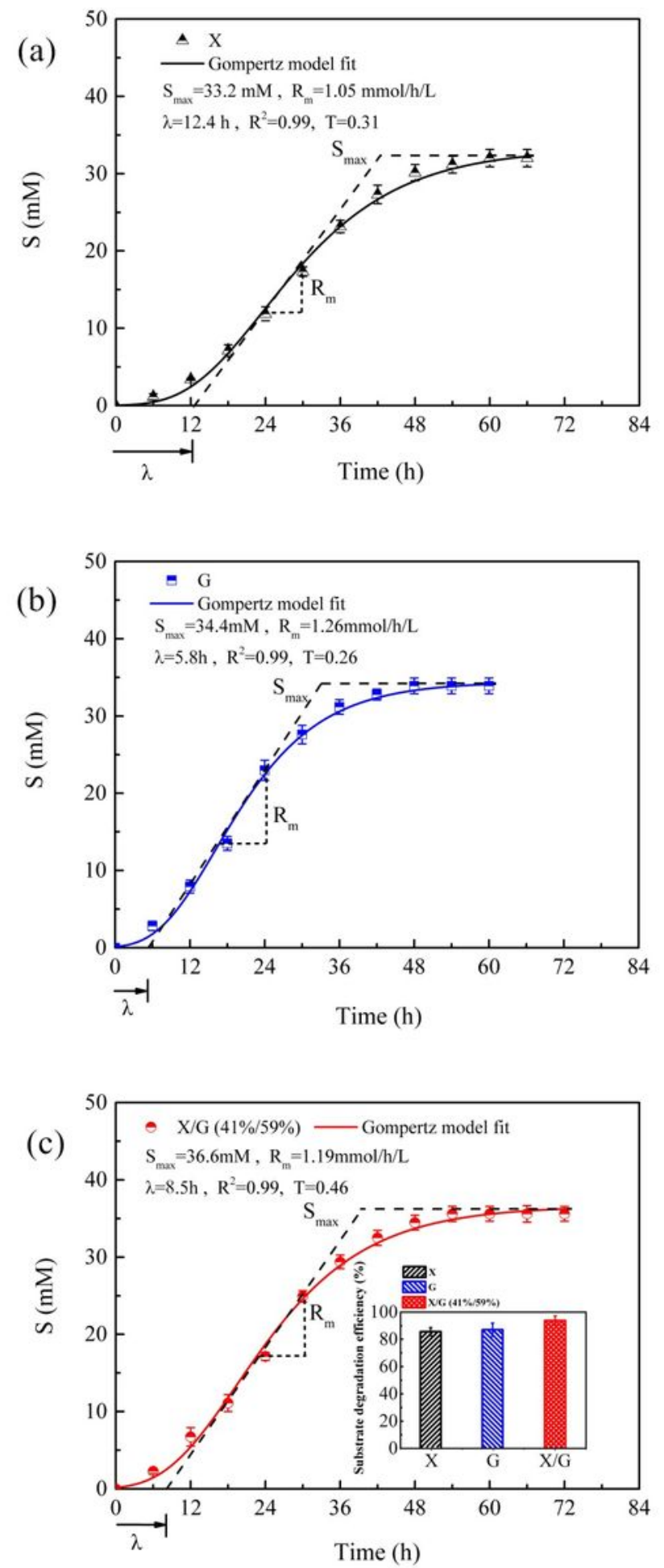

\section{Figure 6}

Substrate consumption rate at optimum conditions from (a) pure xylose, (b) pure glucose and (c) the formulated carbon substrate 